\title{
The Illusions of Progress
}





\title{
Georges Sorel
}

\section{$\propto$ The

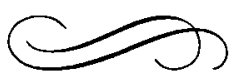 \\ Illusions of Progress}

\author{
translated by \\ Fobn and Charlotte Stanley \\ with a foreword by \\ Robert A. Nisbet \\ and an introduction by \\ Fobn Stanley
}

University of California Press

Berkeley, Los Angeles, London 


\section{University of California Press \\ Berkeley and Los Angeles, California \\ University of California Press, Ltd. \\ London, England}

Copyright (C) 1969 by The Regents of the University of California First Paperback Edition 1972

ISBN: 0-520-02256-4

Library of Congress Catalog Card Number: 69-16511

Printed in the United States of America 